\title{
Interactive Effect of Land Preparation Methods and Weeding Frequency on Seasonal Soil Properties and Maize Yield
}

\author{
S. Appah and S. H. M Aikins
}

\begin{abstract}
Dynamics of soil physical properties and maize yield were investigated in both major and minor cropping seasons under different land preparation methods and weeding frequency. A factorial design experiment was organized on a randomized complete block design with three replicates. The land preparation methods were plough + harrow $(\mathbf{P}+\mathbf{H})$ and no-tillage (NT) while weeding frequency treatments comprised 0, 1, 2 and 3-hoeing regimes. In both seasons, $\mathrm{P}+\mathrm{H}$ yielded good penetration resistance and bulk density, high moisture content and total porosity, and maximum total grain yield than NT. Also, agitating the soil surface at different weeding frequency improved soil physical properties and maize yield parameters. Furthermore, lower penetration resistance and bulk density but higher moisture content and porosity were recorded on hoeing regime(s) than 0-hoeing. The interactive effect of land preparation methods versus weeding frequency on soil properties was significant except penetration resistance during minor season and total porosity during major season. Maximum total grain yield was obtained from $\mathbf{P}+\mathbf{H}$ vs 2 -hoeing treatment plots in both seasons. Generally, increasing weeding frequency on $\mathbf{P}+\mathbf{H}$ plots enhanced soil physical properties and maize yield than NT treatment plots. Therefore, to obtain suitable seasonal soil conditions for crop production, cultivable soils should be ploughed, harrowed and hoed twice at 2nd and 5th weeks after ploughing (WAP).
\end{abstract}

Index Terms - Soil properties, land preparation methods, weeding frequency, minor and major season.

\section{INTRODUCTION}

The capability of soil in land use system to support crop development is based on its quality and properties [1]. It constitutes the topmost medium for crop growth and development [2]. The soil is an embodiment of both abiotic and biotic properties suitable for crop root interactions such as nutrients and organic matter [3], [4]. In soil, many different activities result in its bulk function of structure, stabilization and mineralization for crop growth and yield [5], but surface vegetation influences its maturity. Crop development is aided considerably by soil physical environments. A good soil is friable, porous to percolate and retain water at field capacity for roots elongation and span. It ensures effective nutrient and water transport but depletes its resources when it is subjected to cultivation practices. The soil-root development occurs through interrelationship between physical, chemical and biological properties [6]. Many soil classifications such as

Published on October 3, 2020.

S. Appah, $(\mathrm{PhD})$, Abetifi Presbyterian College of Education, Ghana (e-mail: askappah@yahoo.com). loamy and sandy-loam have good properties favourable for crop production but are subject to change depending on husbandry practices adopted by farmers and climatic conditions.

In crop production, land preparation is the preliminary stage activity. The most commonly used methods are either slash and burn [7], slashing, hoeing or herbicide application [8], ploughing or plough and harrow [9]. The choice of a particular method relies on the vegetation cover, crop type, timeliness of production and ability to preserve soil properties [10]. Tillage breaks soil lump into fine tilth to provide suitable voids for water infiltration and aeration [11]. The exposure of soil during land preparation results in its resource dynamics [12]. While no tillage maintains biophysical properties of soil, mechanical tillage systems disrupt the soil surface but open it up for easy planting operations [13]. Though agitating the soil during ploughing pulverizes and buries debris which decomposes to improve soil structure, the rippling effect on soil resources deserves consideration [14]. Aikins and Afuakwa, [15] indicate that plough and harrow fields provide good soil properties with low penetration resistance than no tillage soils. Total soil bulk density is high under no tillage fields than plough and harrow during crop production but inversely to moisture content [16] and porosity [12]. Moreover, soils that are ploughed and harrowed tend to grow less weeds than no tillage fields under cultivation depending on the cropping season.

Weeding after planting at various stages of crop growth invariably affects soil physical properties [17]. Since crops scarcely compete with weeds for soil resources, land preparation method chosen must be able to reduce weeds emergence so that weeding frequency can be minimized. Weeds [18] are cleared by cultural, chemical or mechanical means [8]. The degree of soil impact at weed control section determines the extent to which soil physical properties are disturbed. Comparatively, destruction differs under hand hoeing, herbicides spraying or mechanical system. Information on changes in soil properties under different weeding methods and frequency regimes is scanty. Though extensive research had been conducted to measure distinct effect of tillage practices on soil properties [15], [19], the interactive effect of different land preparation methods and weeding frequency on soil physical properties and maize yield at different cropping seasons has not been ascertained.

S. H. M. Aikins, (Prof), Department of Agricultural and Biosystems Engineering, Kwame Nkrumah University of Science and Technology, Ghana.

(corresponding email: stephenaikins@yahoo.com) 
Therefore, the objectives of this study were to; (1) determine the seasonal dynamics of soil physical properties and maize yield under different land preparation methods and weeding frequency on cultivated soils and (2) assess the interactive effect of land preparation methods and weeding frequency on soil physical properties and maize yield in both minor and major cropping season.

\section{MATERIALS AND METHODS}

An experiment was carried out to assess seasonal soil physical properties and maize yield under different land preparation methods and weeding frequency. A factorial design was chosen for the study and organized on three replicates randomized complete blocks (RCBD) with two land preparation methods and four weeding frequency. The land preparation treatments consisted of no-tillage (NT) and plough + harrow $(\mathrm{P}+\mathrm{H})$ while weeding frequency treatments were 0 -hoeing, 1 -hoeing at 2 weeks after planting (WAP), 2hoeings at $2 \& 5 \mathrm{WAP}$ and 3 -hoeings at 2, $5 \& 7 \mathrm{WAP}$. Weeding was carried out using hand hoe of $1.5 \mathrm{~kg}$ stainless steel blade, $22.5 \mathrm{~cm}$ height, $17.5 \mathrm{~cm}$ cutting edge and $100 \mathrm{~cm}$ long wooden handle. Each plot size was measured $3 \mathrm{~m} \times 3.5$ $\mathrm{m}$ with $3 \mathrm{~m}$ inter and intra buffer zones for non-destructive movement on and across the field. In all, there were 8 plots per block and 24 plots per experimental land area of approximately 0.1 ha. The plots were pegged to the required dimensions and slashed-off with a $35.3 \mathrm{~kW}$ tractor slashing equipment. Each treatment plot was disc ploughed and further harrowed to the experimental design configuration at two weeks interval. Afterwards, Akposoe maize seeds were sown 2 seeds/hill at $0.75 \mathrm{~m} \times 0.35 \mathrm{~m}$ planting interval to yield approx. 76, 200 seeds ha $^{-1}$ population. The research was carried out on a well-drained sandy loam under Ferric Acrisol soil classification [20]. It was conducted in two successive years at Crop and Soil Sciences Department field, Kwame Nkrumah University of Science and Technology, Ghana. The dynamics of soil physicochemical properties and seasonal (major and minor) fluctuations of monthly mean climatic conditions at the site were analysed (Table 1).

TABLE 1: Monthly MEAn Climatic Conditions AND SEASONAL SoIL PHYSICOCHEMICAL PROPERTIES OF THE EXPERIMENTAL SITE

\begin{tabular}{|c|c|c|c|c|c|}
\hline Month & $\begin{array}{l}\text { Temperature } \\
\left({ }^{\circ} \mathrm{C}\right)\end{array}$ & $\begin{array}{l}\text { Rainfall } \\
(\mathrm{mm})\end{array}$ & Soil properties & $\begin{array}{l}\text { Minor } \\
\text { season }\end{array}$ & $\begin{array}{l}\text { Major } \\
\text { season }\end{array}$ \\
\hline January & 25.95 & 20.2 & Sand \% & 64.59 & 78.72 \\
\hline February* & 27.50 & 66.6 & Silt \% & 29.41 & 16.28 \\
\hline March* & 27.55 & 256.4 & Clay $\%$ & 6.00 & 5.01 \\
\hline April* & 28.10 & 157.4 & Organic matter $\%$ & 1.90 & 1.33 \\
\hline May & 27.60 & 149.9 & Organic Carbon \% & 2.04 & 0.77 \\
\hline June & 26.86 & 197.7 & $\mathrm{pH}$ & 4.83 & 5.40 \\
\hline July & 25.40 & 247.6 & Total N (\%) & 0.10 & 0.06 \\
\hline August & 25.50 & 134.9 & $\mathrm{Ca}^{+}\left(\mathrm{cmol} \mathrm{kg}^{-1}\right)$ & 3.07 & 1.74 \\
\hline September** & 25.80 & 201.8 & $\mathrm{Mg}\left(\mathrm{cmol} \mathrm{kg}^{-1}\right)$ & 0.40 & 0.67 \\
\hline October** & 22.50 & 163.3 & $\mathrm{~K}\left(\mathrm{cmol} \mathrm{kg}^{-1}\right)$ & 0.13 & 0.18 \\
\hline November** & 27.00 & 111.1 & $\mathrm{NH}_{4}+\mathrm{N}\left(\mathrm{cmol} \mathrm{kg}^{-1}\right)$ & 4.25 & 0.94 \\
\hline \multirow[t]{2}{*}{ December } & 27.20 & 47.0 & $\mathrm{P}\left(\mathrm{cmol} \mathrm{kg}^{-1}\right)$ & 11.96 & 19.7 \\
\hline & & & $\mathrm{Na}\left(\mathrm{cmol} \mathrm{kg}^{-1}\right)$ & 0.35 & 0.04 \\
\hline
\end{tabular}

Note: Major season (*) and Minor season (**).
Furthermore, measurements of soil physical properties; penetration resistance, bulk density, moisture content and total porosity were taken before planting ( $0 \mathrm{WAP})$, 5th WAP and 10th WAP in both major and minor cropping seasons. On each of the 24 plots per season, a pocket penetrometer [21], [22] was firmly pushed into the soil at $0-30 \mathrm{~cm}$ depths at 10 randomly selected points to determine penetration resistance. The penetrometer readings observed in $\mathrm{kg} \mathrm{cm}^{2}$ were converted to $\mathrm{kPal}$ and their means computed for statistical analysis. For dry bulk density, moisture content and total porosity, the soil samples at 0-30 $\mathrm{cm}$ depths were used [19]. A core sampler of $5 \mathrm{~cm}$ diameter and $5 \mathrm{~cm}$ height $\left(98.21 \mathrm{~cm}^{3}\right.$, $\pi=22 / 7$ ) was carefully pushed into the soil from the top at 5 $\mathrm{cm}$ depth intervals to a $30 \mathrm{~cm}$ depth. Each undisturbed soil sample excavated by the sampler was trimmed to the true volume, bagged in black polyethylene film sheet, labelled and transported to laboratory for analysis.

The samples were weighed, oven dried in metallic containers of known volume for 24 hours at $105^{\circ} \mathrm{C}$ [15], and reweighed for soil properties determination. Soil bulk density $(\mathrm{Mg} \mathrm{m}-3)$ was computed as a ratio of mass of soil $\left(M_{s}\right)$ to soil volume $\left(V_{t}\right)\left[\rho_{d}=M_{s} / V_{t}\right]$ [23]. The soil moisture content (mc) available within soil pores was determined by gravimetric method using mass of moisture in the soil sample $\left(M_{w}\right)$ and the mass of the dry soil $\left(M_{s}\right)$ where $[m c=$ $\left.M_{w} / M_{s}\right]$. Total porosity $(\varphi)$ was calculated from bulk density with an assumed particle density of $2.6 \mathrm{Mg} \mathrm{m}^{-3}$ as [ $\left.\varphi=1-\left(\rho_{d} / \rho_{s}\right)\right]$ [24]. Dynamics of soil physicochemical properties (Table 1) of soil sample obtained from the field before ploughing were analyzed in KNUST Agricultural Laboratory.

At physiological maturity of hard dough stage, maize ear from six plants at the inner region of each plot was harvested, shelled and open dried in a sun for seven days to reach $13 \%$ grain moisture content. Grain mc was determined from oven drying of 25 grains at $105{ }^{\circ} \mathrm{C}$ for $14 \mathrm{~h}$. The weight of fresh and dried ear were recorded as well as 1000 grain weight and total grain yield from each plot using electronic balance. The ratio of economic yield $\left(\mathrm{kg} \mathrm{ha}^{-1}\right)$ to biological yield $\left(\mathrm{kg} \mathrm{ha}^{-1}\right)$ is given as harvest index (\%). An economic yield is the grain weight while biological yield is the weight of all other parts of the maize plant.

A generalized linear factorial model procedure in Minitab Statistical Software Release 15 [25] was used to statistically analyze the data at $\mathrm{p}<0.05$. All treatment means and interactions effects were computed using least significant difference $\left(t_{\propto / 2}\right)$.

\section{RESUlTS AND DISCUSSION}

Rainfall regimes influence the period at which crops are cultivated without artificial irrigation system. There was seasonal effect on both soil properties and maize yield at different land preparation methods and weeding regimes.

\section{A. Effect of Land Preparation Methods and Weeding Frequency on Seasonal Soil Properties \\ 1. Penetration Resistance}

The variability of soil resistance to penetration with respect to depth in both major and minor cropping seasons under different land preparation methods is shown (fig.1). Soil 
penetration resistance increased with depth in acrisol soils and it was higher in no-tillage fields than plough + harrow plots. Measured values were below the acceptable restrictive range of 1000-2000 kPa for root growth [26,] [27]. In notillage plots, a high penetration resistance of $412.5 \mathrm{kPa}$ and $219.3 \mathrm{kPa}$ were recorded than plough + harrow of $335.7 \mathrm{kPa}$ and $140.8 \mathrm{kPa}$ depth in minor and major seasons respectively. The results shown that it was easier to penetrate through soils on plough and harrow fields than no tillage soils irrespective of the cropping season [16]. The workability of soil mass in crop production is an important phenomenon in ensuring crop root expansion, elongation and planting operation [28]. For roots to reach maximum depth and span, the soil should be friable because compact soils restrict root growth [29], [30].

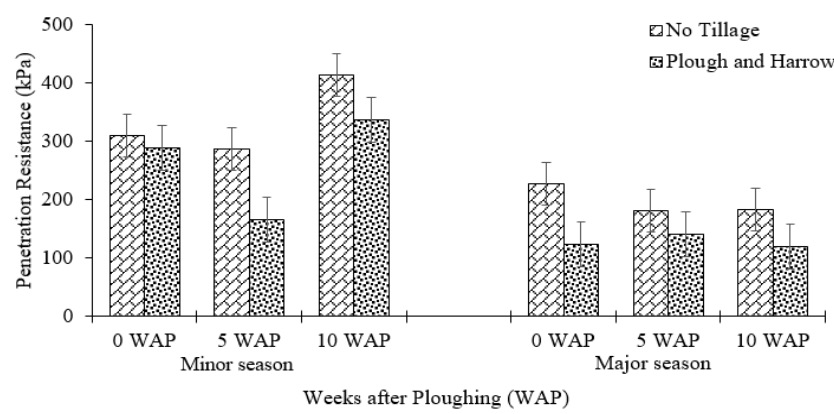

Fig. 1. Effect of Land Preparation Methods on Seasonal Soil Penetration Resistance.

Additionally, frequency of weeding had significant effect on soil penetration resistance in both major and minor cropping seasons (Fig. 2). In minor season, penetration resistance decreased with time from the start of the experiment to 5 WAP and increased accordingly to 10 WAP, but major seasons gave marginal decline of penetration resistance. There was significant difference between hoeing regimes at $10 \mathrm{WAP}$ in minor season without any observed significant differences in the major cropping season. The 0hoeing recorded the highest $(422.6 \mathrm{kPa})$ penetration resistance while 2-hoeing yielded the lowest $(340.0 \mathrm{kPa})$ penetration resistance at $10 \mathrm{WAP}$ in minor season. Though 0 hoeing again produced higher resistance in the major season, there was no significant difference among treatment means with respect to 1,2 and 3 hoeing frequency. The lower penetration resistance values recorded in the major season was because of turning the topsoil by hoeing which broke the cohesive forces in soil structure to reduce penetration resistance. But exposing soil surface to a period of drought in minor season made the soil surface harder to penetrate.

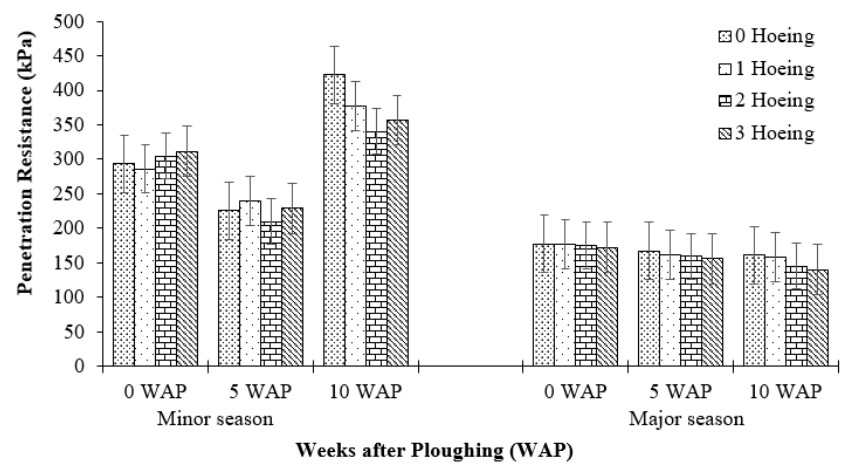

Fig. 2. Effect of Weeding Frequency on Seasonal Soil Penetration Resistance $(\mathrm{kPa})$.

\section{Bulk Density}

Soil bulk density is a measure of soil pack per given volume, hence loosed soils have lower bulk density than compact soils [31]. The friability and compactness of soil mass was influenced by land preparation methods at different cropping seasons. The bulkiness of soil was comparatively high under no-tillage than plough + harrow in both minor and major seasons (Fig 3). During the minor season, bulk density was $1.418 \mathrm{Mg} \mathrm{m}^{-3}$ at $0 \mathrm{WAP}$ but increased to $1.499 \mathrm{Mg} \mathrm{m}^{-3}$ at $5 \mathrm{WAP}$ and declined to 1.486 at $10 \mathrm{WAP}$ on no-tillage plots; values which were higher than bulk densities obtained under plough + harrow plots. Also in major season, there was decline in bulk densities with no-tillage being higher than plough + harrow as well. Both seasonal values depicted similar rise and fall in bulk densities and the values were within the range of $1.0-1.9 \mathrm{Mg} \mathrm{m}^{-3}$ bulk density for mineral soils [32]. The bulk densities obtained at 10 WAP presented a statistically significant difference in both major and minor seasons, indicating that land preparation methods had overall effect on soil bulk density.

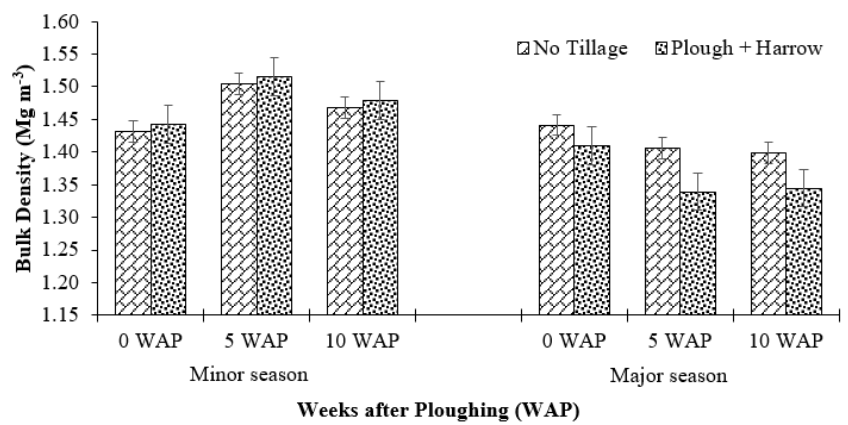

Fig. 3. Effect of Land Preparation Methods on Seasonal Soil Bulk Density.

The hoeing regimes turned to break surface structure of soil than deeper depths, hence significantly influenced surface bulk density in both major and minor cropping seasons (Fig. 4). Over the period of the experiment, 0-hoeing recorded the highest bulk density than 1, 2 and 3-hoeing regimes. Also, soil bulk density maximized at 5 WAP and decreased at 10 WAP during minor season, whereas an appreciable increase in bulk density was observed up to 10 WAP in the major season. In both seasons, 0 -hoeing plots produced higher bulk densities at $10 \mathrm{WAP}$, hence weeding pulverized soil to reduce bulk density.

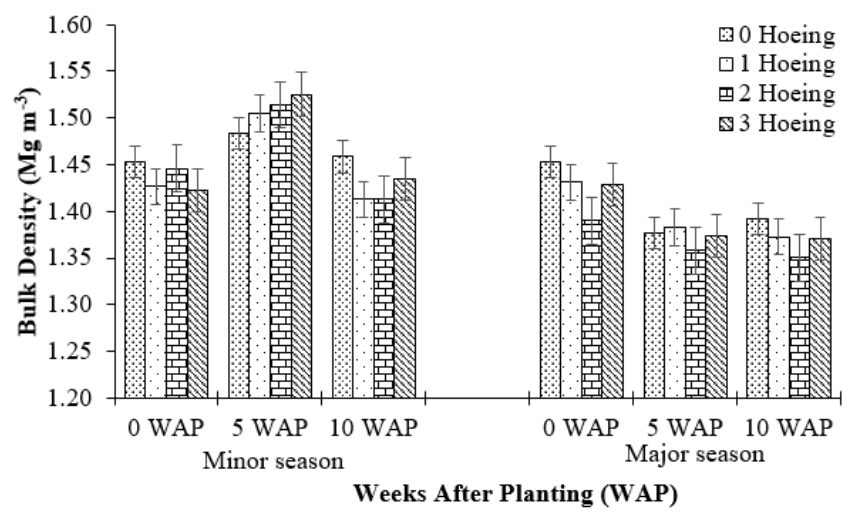

Fig. 4. Effect of Weeding Frequency on Seasonal Soil Bulk Density $\left(\mathrm{Mg} \mathrm{m}^{-3}\right)$. 


\section{Moisture Content}

In rain-fed agriculture, variations in seasonal rainfall pattern determine the amount of moisture that can be entrained in soil voids per given time, while land preparation methods regulate soil moisture content. Soil pulverization during plough + harrow increased soil voids to improve on water retention capacity in the soil. As in figure 5, the moisture content values obtained from plough + harrow plots were higher than no-tillage plots, results which contradict research findings of Azooz et al., [33] but conforms to Aikins and Affuakwah [15]. Notably, moisture content was maximum $(13 \%)$ at $5 \mathrm{WAP}$ in the minor season, while there was an increase in the major season to $(21.01 \%)$ at $10 \mathrm{WAP}$ under plough + harrow plots than no tillage plots. The seasonal variations in soil moisture content could be attributed to temperature and rainfall fluctuations during the period of the experiment.

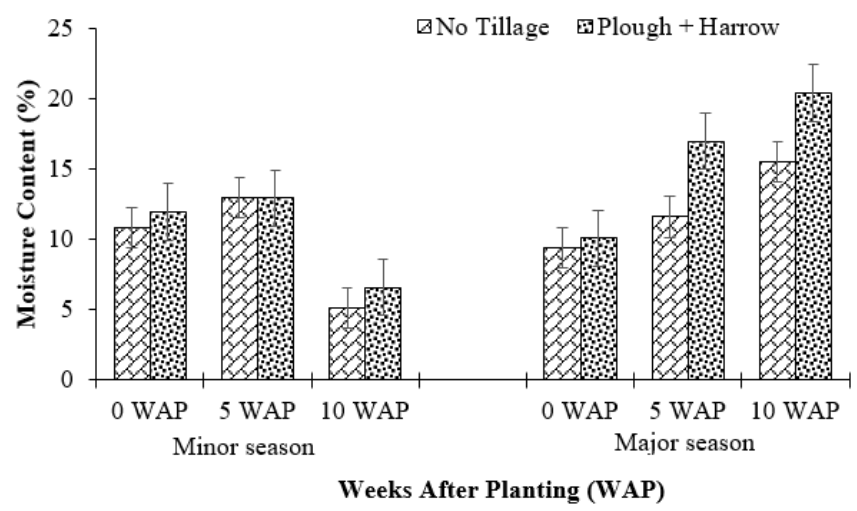

Fig. 5. Effect of Land Preparation Methods seasonal moisture content.

Fig. 6 presents weeding frequency effect on soil moisture content in both minor and major cropping seasons. Moisture content decreased in minor season and increased in the major season at different weeding frequency. During the major season, moisture content was highest under 2-hoeing $(19.39 \%)$ at 10 WAP regime than minor season than all other weeding regimes. The exposure of the soil surface at different weeding frequency to a period of drought in the minor season accounted for the decline in moisture content, contrary to Faria et al. [17]. But hoeing in the major season opened-up the soil surface to allow water infiltration and retention for maximum moisture content at different weeding regimes. Also, rapid decomposition of weeds after hoeing in major season resulted in high moisture retention but less rainfall in the minor cropping season did not favour debris decay, hence lower moisture contents at different weeding frequency.

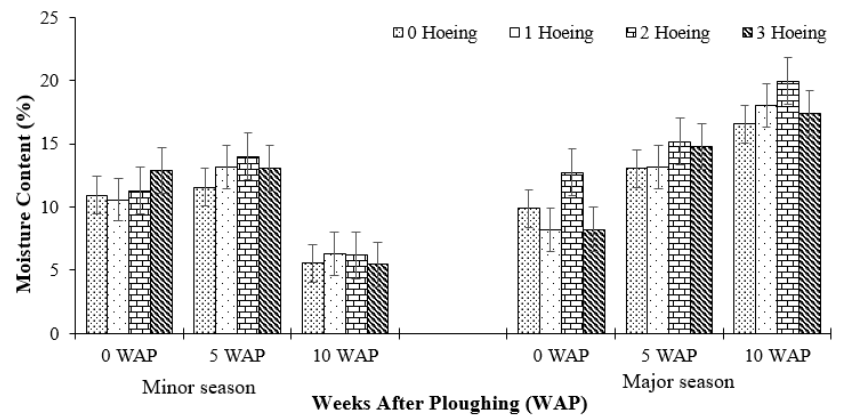

Fig. 6. Effect of Weeding Frequency on Seasonal Soil Moisture Content.

\section{Total Porosity}

Effect of land preparation methods on soil porosity in both minor and major cropping seasons is given in Fig 7. Soil porosity accounted for variations of water and air contents in soil void. The continuity of soil pores with different sizes and shapes affected water storage and drainage [34]. Plough + harrow treatment produced higher values of soil total porosity than no-tillage treatment in both cropping seasons [35]. Plough + harrow gave higher porosity $(49.91 \%)$ as against no tillage $(47.1 \%)$ in the major season, a phenomenon indicating more pore spaces for maximum productivity [36]. The differences in data came as a result of burying and decomposition of debris during plough + harrow operations which improved pore spaces.

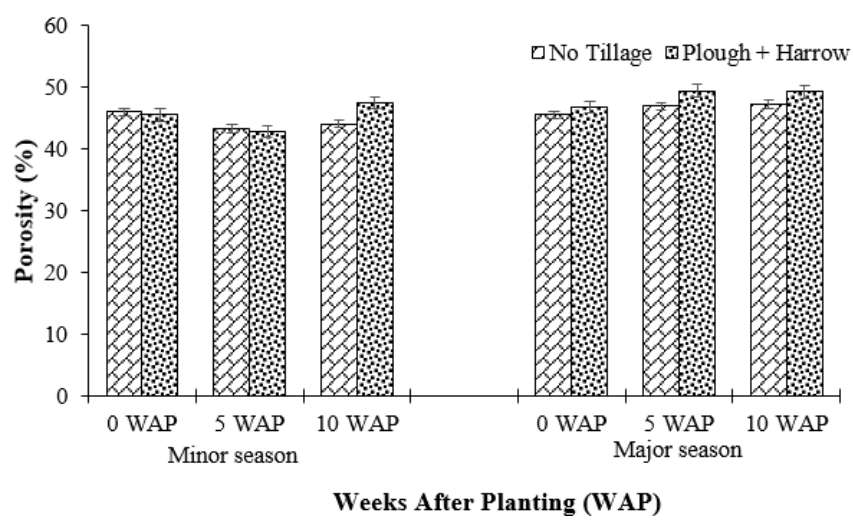

Fig. 7. Effect of Land Preparation Methods on Seasonal Total Porosity.

Moreover, at saturation point, air void is almost zero which rises at field capacity and reaches its peak at permanent wilting point in an alternating levels of water void. There was seasonal variations in total porosity with time due to weeding frequency (Fig. 8). In the major season, 2-hoeing produced maximum $(49.63 \%)$ porosity while 0 -hoeing gave the minimum $(47.3 \%)$ porosity, but in the minor season, porosity decreased at 5 WAP and rose to peak levels at 10 WAP. In both seasons, hoeing regimes exhibited higher porosity values than 0 -hoeing treatment. The hand hoeing resulted to breaking the soil lump at the surface layer to create micro and macro pores in soil medium for an aeration and water retention.

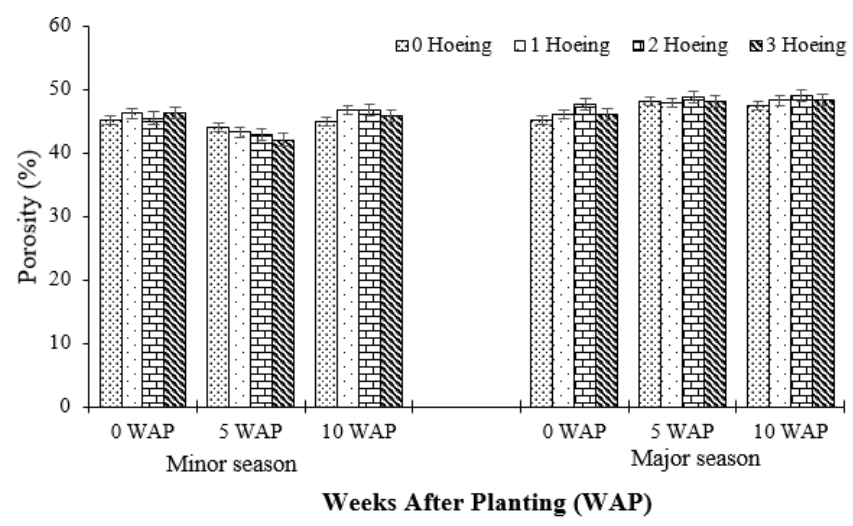

Fig. 8. Effect of Weeding Frequency on Soil Total Porosity. 


\section{B. Interaction effect of land preparation methods and} weeding frequency on soil properties

Generally, there was an interactive effect of land preparation methods and weeding frequency on surface penetration resistance, bulk density, moisture content and porosity in both seasons (Table 2). Though seasonal variations in soil properties ensued, there was significant differences in bulk density, moisture content and total porosity except penetration resistance during minor season whiles in major season significant differences existed in penetration resistance, bulk density, moisture content, except total porosity. The interaction between plough + harrow and weeding frequency treatments produced lower penetration resistance and porosity but higher moisture content and bulk density. Whereas, no-tillage vs weeding frequency treatments yielded higher penetration resistance and porosity but lower moisture content and bulk density. To obtain an ideal soil physical properties for cultivation throughout a particular cropping season, the land should be ploughed, harrowed and weeds cleared with a hand hoe, preferably 3-hoeing regimes at 2nd, 5th and 7th WAP for economic gains.

TABLE 2: INTERACTIVE EFFECT OF LAND PREPARATION METHOD AND WEEDING FREQUENCY ON SEASONAL SOIL PHYSICAL PROPERTIES AT 10 WAP

\begin{tabular}{|c|c|c|c|c|c|c|c|c|}
\hline \multirow{2}{*}{$\begin{array}{l}\text { Land Preparation } \\
\text { Method } \mathrm{x} \\
\text { Weeding } \\
\text { Frequency }\end{array}$} & \multicolumn{4}{|c|}{ Minor Season } & \multicolumn{4}{|c|}{ Major Season } \\
\hline & $\begin{array}{c}\text { Penetration } \\
\text { resistance } \\
\quad \mathrm{kPa}\end{array}$ & $\begin{array}{c}\text { Bulk } \\
\text { density } \\
\mathrm{mg} \mathrm{m}^{-3}\end{array}$ & $\begin{array}{c}\text { Moisture } \\
\text { Content } \\
\%\end{array}$ & $\begin{array}{c}\text { Total } \\
\text { Porosity } \\
\%\end{array}$ & $\begin{array}{c}\text { Penetration } \\
\text { resistance } \\
\mathrm{kPa}\end{array}$ & $\begin{array}{l}\text { Bulk density } \\
\mathrm{Mg} \mathrm{m}^{-3}\end{array}$ & $\begin{array}{c}\text { Moisture } \\
\text { Content \% }\end{array}$ & $\begin{array}{c}\text { Total } \\
\text { Porosity } \\
\%\end{array}$ \\
\hline $\begin{array}{l}\text { No Tillage } \mathrm{x} 0 \\
\text { Hoeing }\end{array}$ & 291.4 & 1.4785 & 10.12 & 44.22 & 170.4 & 1.3900 & 10.91 & 47.55 \\
\hline $\begin{array}{l}\text { No Tillage } \mathrm{x} 1 \\
\text { Hoeing }\end{array}$ & 320.3 & 1.4820 & 15.12 & 44.08 & 175.6 & 1.4190 & 10.81 & 46.44 \\
\hline $\begin{array}{l}\text { No Tillage } \times 2 \\
\text { Hoeing }\end{array}$ & 243.1 & 1.4995 & 14.01 & 43.40 & 202.0 & 1.3995 & 11.55 & 47.19 \\
\hline $\begin{array}{l}\text { No Tillage } \mathrm{x} 3 \\
\text { Hoeing }\end{array}$ & 293.0 & 1.5550 & 12.58 & 41.32 & 174.4 & 1.4160 & 13.22 & 46.57 \\
\hline $\begin{array}{l}\text { Plough + Harrow } \\
\mathrm{x} 0 \text { Hoeing }\end{array}$ & 160.4 & 1.4885 & 13.04 & 43.82 & 163.0 & 1.3645 & 16.51 & 48.52 \\
\hline $\begin{array}{l}\text { Plough + Harrow } \\
\text { x } 1 \text { Hoeing }\end{array}$ & 159.9 & 1.5285 & 11.24 & 42.33 & 147.3 & 1.3470 & 15.38 & 49.18 \\
\hline $\begin{array}{l}\text { Plough + Harrow } \\
\text { x } 2 \text { Hoeing }\end{array}$ & 176.4 & 1.5280 & 13.97 & 42.34 & 116.0 & 1.3165 & 18.79 & 50.32 \\
\hline $\begin{array}{l}\text { Plough + Harrow } \\
\text { x } 3 \text { Hoeing }\end{array}$ & 165.3 & 1.5160 & 13.62 & 42.80 & 136.8 & 1.3315 & 17.35 & 49.76 \\
\hline $\operatorname{LSD}(\mathrm{p}<0.05)$ & NS & 0.05 & 2.29 & 1.98 & 1.08 & 0.02 & 2.33 & NS \\
\hline
\end{tabular}

effects of tillage treatment on yield of maize by Ogan [37].

C. Effect of Land Preparation Methods and Weeding Frequency on Maize Yield Components

Table 3 shows the effect of land preparation methods on seasonal harvest index, shelling percentage, 1000 SeedWeight and Total Grain Yield of maize. In both seasons, 1000 grain yield and corresponding total grain yield were statistically significant. Plough + harrow treatment produced highest index of harvest which resulted in maximum total yield than no tillage treatment. This opposed non-significant
The higher the harvest index and shelling percentage, the more total grain yield of Akposoe maize is expected from the field, since more grains would be obtained during shelling. The plough + harrow plots produced higher total grain yield of (6548 kg ha-1 in minor season and $\left.6635 \mathrm{~kg} \mathrm{ha}^{-1}\right)$ in the major season than no tillage plots. To optimize Akposoe maize yield, there is the need to plough and harrow the land before planting [13].

TABLE 3: EFFECT OF LAND PREPARATION METHODS ON MAIZE YIELD PARAMETERS

\begin{tabular}{|c|c|c|c|c|c|c|c|c|}
\hline \multirow{2}{*}{$\begin{array}{l}\text { Land } \\
\text { Preparation } \\
\text { Method }\end{array}$} & \multicolumn{4}{|c|}{ Minor Season } & \multicolumn{4}{|c|}{ Major Season } \\
\hline & $\begin{array}{c}\text { Harvest } \\
\text { Index }\end{array}$ & $\begin{array}{l}\text { Shelling } \\
\text { Percentage }\end{array}$ & $\begin{array}{l}1000 \text { grain } \\
\text { yield } \mathrm{g}\end{array}$ & $\begin{array}{c}\text { Total grain } \\
\text { yield kg } \\
\mathrm{ha}^{-1}\end{array}$ & $\begin{array}{c}\text { Harvest } \\
\text { Index } \\
\%\end{array}$ & $\begin{array}{c}\text { Shelling } \\
\text { Percentage } \\
\%\end{array}$ & $\begin{array}{c}1000 \\
\text { grain } \\
\text { yield } g\end{array}$ & $\begin{array}{c}\text { Total } \\
\text { grain } \\
\text { yield kg } \\
\mathrm{ha}^{-1}\end{array}$ \\
\hline No Tillage & 55.69 & 53.60 & 208.8 & 5008 & 57.25 & 53.18 & 210.7 & 4686 \\
\hline $\begin{array}{l}\text { Plough + } \\
\text { Harrow }\end{array}$ & 59.19 & 57.04 & 225.9 & 6548 & 64.38 & 58.87 & 227.8 & 6635 \\
\hline LSD $(p<0.05)$ & NS & NS & 13.29 & 1083.78 & NS & 6.30 & 13.31 & 920.31 \\
\hline
\end{tabular}

Similarly, weeding frequency statistically affected 1000 grain yield and total grain yield in both minor and major seasons (Table 4). The 2-hoeing plots recorded the highest total grain yield in both minor season $\left(7202 \mathrm{~kg} \mathrm{ha}^{-1}\right)$ and major seasons (6846 $\left.\mathrm{kg} \mathrm{ha}^{-1}\right)$ corresponding to their respective harvest index of $58.80 \%$ and $58.15 \%$ respectively. This indicates that harvest index and shelling percentage for Akposoe maize are maximised when farms are weeds-free, 
but would duly reduce when maize plants are allowed to compete with weeds from time of planting to physiological maturity and harvest. The 0 -hoeing gave the least total grain yield (2969 $\left.\mathrm{kg} \mathrm{ha}^{-1}\right)$ and $\left(2912 \mathrm{~kg} \mathrm{ha}^{-1}\right)$ respectively in the minor and major seasons. Maize yield is reduced if weeds are not controlled [38]. Hand hoeing twice during the production period is recommended to achieve highest maize yield [38], due to increased moisture content in the soil [39].

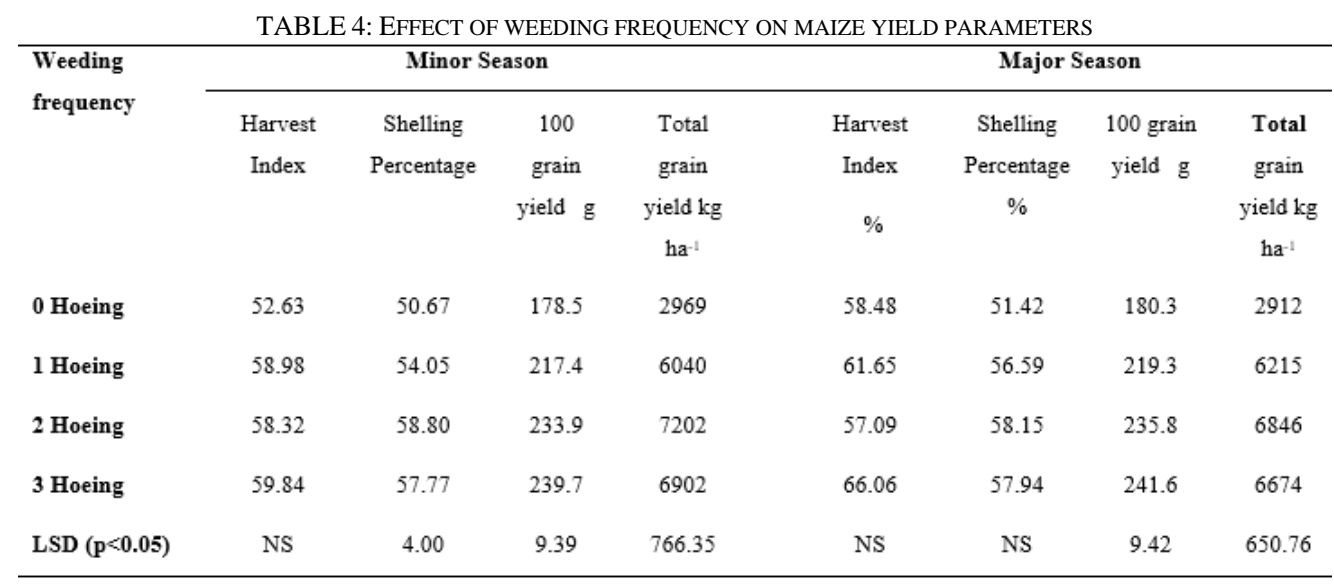

D. Interaction effect of land preparation methods and weeding frequency on maize yield components

In both minor and major seasons, harvest index and shelling percentage were not significant whereas 1000 grain weight and total grain yield showed statistically significant differences at interaction between land preparation methods and weeding frequency (Table 5). Plough + harrow vs 2hoeing produced maximum total grain yield in both seasons while no tillage vs 0-hoeing yielded the least total grain yield.

\begin{tabular}{|c|c|c|c|c|c|c|c|c|}
\hline \multirow[b]{2}{*}{$\begin{array}{l}\text { Land Preparation } \\
\text { Method } \mathrm{x} \\
\text { Weeding } \\
\text { Frequency }\end{array}$} & \multicolumn{4}{|c|}{ Minor Season } & \multicolumn{4}{|c|}{ Major Season } \\
\hline & $\begin{array}{l}\text { Harvest } \\
\text { Index } \\
\%\end{array}$ & $\begin{array}{c}\text { Shelling } \\
\text { percentage } \\
\%\end{array}$ & $\begin{array}{c}1000 \\
\text { grain } \\
\text { weight g }\end{array}$ & $\begin{array}{c}\text { Total } \\
\text { grain } \\
\text { yield kg } \\
\mathrm{ha}^{-1} \\
\end{array}$ & $\begin{array}{c}\text { Harvest } \\
\text { Index } \\
\%\end{array}$ & $\begin{array}{c}\text { Shelling } \\
\text { percentage } \\
\%\end{array}$ & $\begin{array}{c}1000 \\
\text { grain } \\
\text { weight g }\end{array}$ & $\begin{array}{c}\text { Total } \\
\text { grain } \\
\text { yield kg } \\
\mathrm{ha}^{-1} \\
\end{array}$ \\
\hline $\begin{array}{l}\text { No Tillage } \mathrm{x} 0 \\
\text { Hoeing }\end{array}$ & 50.49 & 48.69 & 170.4 & 2159 & 57.43 & 49.56 & 172.2 & 2101 \\
\hline $\begin{array}{l}\text { No Tillage } \mathrm{x} 1 \\
\text { Hoeing }\end{array}$ & 54.30 & 49.78 & 220.6 & 5295 & 57.61 & 50.15 & 222.5 & 5237 \\
\hline $\begin{array}{l}\text { No Tillage } \mathrm{x} 2 \\
\text { Hoeing }\end{array}$ & 59.64 & 58.73 & 217.3 & 6294 & 58.66 & 56.38 & 219.2 & 5525 \\
\hline $\begin{array}{l}\text { No Tillage } \mathrm{x} 3 \\
\text { Hoeing }\end{array}$ & 58.35 & 57.07 & 227.0 & 6286 & 59.30 & 56.65 & 228.9 & 5889 \\
\hline $\begin{array}{l}\text { Plough + Harrow } \\
\mathrm{x} 0 \text { Hoeing }\end{array}$ & 54.77 & 52.65 & 186.6 & 3780 & 59.29 & 53.28 & 188.4 & 3722 \\
\hline $\begin{array}{l}\text { Plough + Harrow } \\
\text { x } 1 \text { Hoeing }\end{array}$ & 56.99 & 58.31 & 214.2 & 6785 & 59.52 & 59.92 & 216.1 & 7193 \\
\hline $\begin{array}{l}\text { Plough }+ \text { Harrow } \\
\text { x } 2 \text { Hoeing }\end{array}$ & 63.67 & 58.87 & 250.6 & 8110 & 74.70 & 63.04 & 252.5 & 8167 \\
\hline $\begin{array}{l}\text { Plough }+ \text { Harrow } \\
\text { x } 3 \text { Hoeing }\end{array}$ & 61.34 & 58.46 & 252.4 & 7517 & 63.99 & 59.23 & 254.2 & 7460 \\
\hline $\operatorname{LSD}(p<0.05)$ & NS & NS & 18.79 & 403.65 & NS & NS & 18.83 & 504.51 \\
\hline
\end{tabular}

\section{CONCLUSION}

Soil physical properties provide a characteristic feature of anchorage, aeration and moisture to Akposoe maize. To determine seasonal effect on soil physical properties and maize yield under different land preparation methods and weeding frequency, an experiment was conducted in both minor and major cropping seasons in Ghana. The experiment was factorially designed on a randomized complete block design (RCBD). No-tillage and plough + harrow were the land preparation methods whiles 0-hoeing, 1-hoeing at 2nd WAP; 2-hoeing at 2nd and 5th WAP; and 3-hoeing at 2nd, 5th, 7th WAP constituted the weeding frequency treatments. Soil samples were taken from treatment plots before planting (0 WAP), 5 WAP and10 WAP from 0-30 cm depth for soil physical properties determination. Akposoe maize seeds were sown on each plot under good husbandry practices till harvest at hard dough stage for grain yield analysis.

Over the entire period of the experiment, higher soil penetration resistance and bulk density were obtained on notillage plots than plough + harrow fields. However, plough + harrow plots gave higher moisture content and total porosity than no-tillage. There was an increased soil moisture content and porosity but low penetration resistance and bulk density 
under plots subjected to weeding treatments than 0-hoeing. Plough and harrow plots produced maximum grain yield than no tillage. The interactive effect of plough + harrow versus weeding frequency on soil physical properties and maize yield gave better results than no-tillage versus weeding regimes. It is therefore important to prepare land by plough and harrow before planting and control weeds by hoeing to improve soil physical properties and maximize yield of maize in acrisol soils.

\section{ACKNOWLEDGEMENT}

The experimental work for this research was funded by the Supervisor and Co-Author, SHM Aikins (Department of Agricultural Engineering, Kwame Nkrumah University of Science \& Technology, Kumasi, Ghana).

\section{REFERENCES}

[1] J. W. Doran and T. B. Parkin, Defining and assessing soil quality. Defining soil quality for a sustainable environment. 1994 May 1; 35: 1 21.

[2] E. J. Russell, Soil Conditions and Plant Growth, Longmans: London, 1961, p.333

[3] G. Den Herder, G. Van Isterdael, T. Beeckman and I. De Smet [November 2010]. The roots of a new green revolution. Trends in plant science [Online]. 15(11). pp. 600-7. Available: https://www.sciencedirect.com/science/article/abs/pii/S136013851000 1780

[4] P. J. Gregory. [February 2006]. Roots, rhizosphere and soil: the route to a better understanding of soil science? European Journal of Soil Science [online]. 57(1). Pp. 2-12. Available: https://onlinelibrary.wiley.com/doi/full/10.1111/j.13652389.2005.00778.x

[5] E. A Stockdale and P. C. Brookes. [August 2006]. Detection and quantification of the soil microbial biomass-impacts on the management of agricultural soils. The Journal of Agricultural Science [Online]. 144(4). pp. 285-302. Available: https://www.cambridge.org/core/journals/journal-of-agriculturalscience/article/detection

[6] A. Hodge [January 2006] Plastic plants and patchy soils. Journal of experimental botany [Online]. 57(2). pp. 401-11. Available: https://academic.oup.com/jxb/article/57/2/401/489917

[7] E. N. Gacheru, M. K. O'Neill, G. M. Kamau, H. M. Saha and G. D. Odhiambo. [January 1993]. Effect of land preparation and weeding on maize (Zea mays) grain yields in the coastal region of Kenya. International Journal of Pest Management [Online]. 39(1). pp 57-60. Available:

https://www.tandfonline.com/doi/abs/10.1080/09670879309371759

[8] A. W. Massawe, W. Rwamugira, H. Leirs, H. R. Makundi and L. S. Mulungu. [2005]. Influence of Land Preparation Methods and Vegetation Cover on Population Abundance of Mastomysnatalensis in Morogoro, Tanzania, Belg. Journal of Zoology [Online]. 135. pp. 187190.

[9] S. H. M. Aikins and J. J. Afuakwa [2010]. Effect of Four Different Tillage Practices on Cowpea Performance. World Journal of Agricultural Sciences [Online]. 6(6). pp. 644-651. Available: http://citeseerx.ist.psu.edu/viewdoc/download?doi=10.1.1.415.5214\& rep=rep $1 \&$ type $=$ pdf

[10] J. D. Jabro, W. B. Stevens, R. G. Evans and W. M. Iversen. [2009]. Tillage Effects on Physical Properties in Two Soils of the Northern Great Plains. Applied Engineering in Agriculture, 25(3). pp. 377-382. Available: https://pubag.nal.usda.gov/catalog/35057

[11] G. D. Massa and S. Gilroy. [February 2003]. Touch Modulates Gravity Sensing to Regulate the Primary Roots of Arabidopsis Thaliana. The Plant Journal [Online]. 33(3). pp. 435 - 445. Available: https://onlinelibrary.wiley.com/doi/full/10.1046/j.1365313X.2003.01637.x

[12] J. W. Elder and R. Lal. [March 2008]. Tillage Effects on Physical Properties of Agricultural Organic Soils of North Central Ohio. Soil \& Tillage Research [Online]. 98(2). pp. 208-210. Available: https://www.sciencedirect.com/science/article/pii/S016719870700220 6
[13] M. Rashidi, F. Keshavarzpour and M. Gholami. [2008]. Effect of Different Tillage Methods on Yield and Yield Components of Forage Corn, American-Eurasian Journal of Agricultural and Environmental Science, 3: 347-351.

[14] S. Ozpinar and A. Isik. [January 2004]. Effects of Tillage, Ridging and Row Spacing on Seedling Emergence and Yield of Cotton. Soil \& Tillage Research [Online]. 75(1): 19-26. Available: https://www.sciencedirect.com/science/article/pii/S016719870300201 0

[15] S. H. M. Aikins and J. J. Afuakwa. [2012]. Effect of Four Different Tillage Practices on Soil Physical Properties under Cowpea Agriculture and Biology Journal of North America [Online], 3(1). pp. 17-24. Available: https://scihub.org/ABJNA/PDF/2012/1/ABJNA-3 1-17-24.pdf

[16] J. O. Olaoye. [March 2002]. Influence of Tillage on Crop Residue Cover, Soil Properties and Yield Components of Cowpea in Derived Savannah Ectones of Nigeria. Soil \& Tillage Research [Online], 64(34): 179-187. Available: https://www.sciencedirect.com/science/article/pii/S016719870100261 6

[17] J. C. Faria, C. E. R. Schaefer, H. A. Ruiz and L. M. Costa. [1998] Effects of Weed Control on Physical and Micropedological Properties of a Brazilian Ultisol. R. Bras. Ci. Solo [Online]. 22. pp. 731-741. Available: https://www.scielo.br/pdf/rbcs/v22n4/19.pdf

[18] O. I. Akobundu and C. W. Agyakwa. A Handbook of West African Weeds (2nd Edn.). International Institute of Tropical Agriculture, African Book Builders Ltd, 1998. Nigeria.

[19] B. A. Senjobi, O. T. Ande and A. E. Okulaja. [July 2013]. Effects of Tillage Practices on Soil Properties under Maize Cultivation on Oxic Paleustalf in South Western Nigeria. Open Journal of Soil Science [Online]. 3(3). pp. 163-168. Available: https://www.scirp.org/journal/paperinformation. aspx? paperid=33800

[20] S. V. Adu. Soils of the Kumasi Region, Ashanti Region, Ghana Memoir No. 8. CSIR-Soil Research Institute, Kumasi, 1992.

[21] D. D. Fritton [June 2008]. Evaluation of pedotransfer and measurement approaches to avoid soil compaction. Soil and Tillage Research [Online]. $269(2): \quad 268 \quad-\quad 278 . \quad$ Available: https://www.sciencedirect.com/science/article/pii/S016719870800058 5

[22] D. Sinnett, G. Morgan, M. Williams and T. R. Hutchings. [September 2008]. Soil penetration resistance and tree root development. Soil Use and Management [Online], 24(3): 273 - 280. Available: https://onlinelibrary.wiley.com/doi/abs/10.1111/j.14752743.2008.00164.x

[23] P. J. Gregory and S. Nortcliff. Soil Conditions and Plant Growth. A John Wiley \& Sons: UK. 2013.

[24] Blanco-Canqui, H., Lal, R. and Post, W. M., Izaurralde, R. C. and Shipitalo, M. J. [July 2006]. Organic Carbon Influences on Soil Particle Density and Rheological Properties. Soil Science Society of America Journal [Online], 70(4): 1407 - 1414. Available: https://acsess.onlinelibrary.wiley.com/doi/abs/10.2136/sssaj2005.035 5

[25] MINITAB Inc. 2007. MINITAB Statistical Software Release 15 for Windows. Minitab Inc. State College, Pennsylvania.

[26] A. Khalilian, C. E. Hood, J. H. Palmer, T. H. Garner and G. R. Bathke. [1991]. Soil Compaction and Crop Response to Wheat/Soybean Interseeding. Transaction of the ASAE [Online]. 34(6), 2299-2303. Available: https://elibrary.asabe.org/abstract.asp?aid=31871

[27] J. G. Benjamin, D. C. Nielsen and M. F. Vigil. [September 2003] Quantifying Effects of Soil Conditions on Plant Growth and Crop Production. Geoderma [Online]. 116(1-2). pp. 137-148. Available: https://www.sciencedirect.com/science/article/abs/pii/S001670610300 0983

[28] A. G. Bengough Root growth and function in relation to soil structure, composition, and strength. In: Root Ecology (eds H. de Kroon and E.J.W. Visser), 2003. pp. 151 - 171. Springer-Verlag, Berlin.

[29] W. W. Emerson, R. C. Foster, J. M. Tisdall and D. Weissmann. [1994]. Carbon Content and Bulk-Density of an Irrigated Natrixeralf in Relation to Tree Root-Growth and Orchard Management. Australian Journal of Soil Research, 32(5). pp. 939 - 951. Available: https://www.publish.csiro.au/sr/SR9940939

[30] K. M. Hati, K. G. Mandal, A. K. Misra, P. K. Ghosh and K. K. Bandyopadhyay. [November 2006]. Effect of Inorganic Fertilizer and Farmyard Manure on Soil Physical Properties, Root Distribution, and Water-Use Efficiency of Soybean in Vertisols of Central India Bioresource Technology [Online]. 97(16). pp. 2182 - 2188. Available: https://www.sciencedirect.com/science/article/abs/pii/S096085240500 4797 
[31] NC, Brady and RR. Weil The nature and properties of soil 12th ed. Mac. Pub. Com. New York. 1999: pp. 625-40.

[32] T. Keller and I. Hakansson. [January 2010]. Estimation of Reference Bulk Density from Soil Particle Size Distribution and Soil Organic Matter Content. Geoderma [Online], 154(3-4). pp. 398 - 406 Available: https://www.sciencedirect.com/science/article/abs/pii/S001670610900 3644

[33] R. H. Azooz, M. A. Arshad and A. J. Franzluebbers [July 1996]. Pore Size Distribution and Hydraulic Conductivity as Affected by Tillage in Northwestern Canada. Soil Sci. Soc. Am. J. [Online]. 60(4): pp. $1197-$ $1201 . \quad$ Available: https://acsess.onlinelibrary.wiley.com/doi/abs/10.2136/sssaj1996.036 $15995006000040034 x$

[34] B. D Kay and A. J. VandenBygaart, [2002]. Conservation Tillage and Depth Stratification of Porosity and Soil Organic Matter. Soil \& Tillage Research, 66: 107-118.

[35] D. K. Cassel, C. W. Raczkowski and H. P. Denton, [1995]. Tillage Effects on Corn Production and Soil Physical Properties, Soil Sci. Soc. Am. Journal, 59: 1436-1443.

[36] Radford, B. J., Yule, D. F., McGarry, D. and Playford, C. 2001. Crop Responses to Applied Soil Compaction and to Compaction Repair Treatments. Soil and Tillage Research, 61: 157-166.

[37] E. A. Ogan, [2004]. Effects of Urea fertilizer application and tillage practices on the growth and yield components of maize, Crop Science Research, 4(3): 311-317.

[38] H.F. Abouziena, M.F. El-Karmany, M. Singh and S.D. Sharma. (2007) Effect of Nitrogen Rates and Weed Control Treatments on Maize Yield and Associated Weeds in Sandy Soils, Weed Technology, 21(10): 4953.

[39] A.R. Adenawoola, R.D. Aladesanwa and T.D. Adenowuro. [2005] Effects of frequency of weeding on the growth and yield of long-fruited jute (Corchorus olitorius) in a rainforest area of southwestern Nigeria, Crop Protection, 24: 407-411.

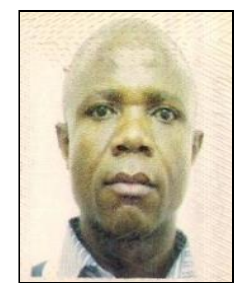

Samuel Appah, Abetifi Presbyterian College of Education, Box 19, Abetifi Kwahu, Ghana, (email: askappah@yahoo.com).PhD in Agricultural Engineering, Jiangsu University, China, 2019; MSc in Agricultural Machinery Engineering, KNUST, Ghana, 2013; BSc in Agricultural Technology (Mechanization and Irrigation Technology), UDS, Ghana, 2007. 